\title{
Apple Growing Areas in Iwate Prefecture, Northern Japan
}

\author{
Norio Hasegawa
}

Because of the complicated physical features in Iwate Prefecture, unique land utilization and farming system can be observed in each area of markedly strong peculiarity, and in addition apple culture newly adopted have established diversified apple growing areas. Apple production in the prefecture has been remarkably developed since the world war, increasing in area by twofold from 4,500 acres in 1949 to 8,900 acres in 1955 , though representing only 5 percent of the output of Japan total."

In this report the outline of the characters of the apple growing areas there is briefly described. And the author attempts to consider the problems as to the formation of a new agricultural region.

\section{Physical Features in Iwate Prefecture}

The Kitakami Mts. occupy 61 percent of the eastern part in extent, and the Ou Mts. traverse in the western part. And the Kitakami River flows between both mountains, forming the Kitakami river basin. The western part of the basin is divided by a tectonic line, and fans develop along it there. The Kitakami Mts. are an elevated peneplain with complicated coastal line of Ria Type. The southern part of the mountains is fairly dissected and shows a hilly land-form. The northern part of the prefecture belongs to the upper part of the Mabechi Valley, and the small plain there is utilized as an agricultural land. Arable lands are agglomerated chiefly in the Kitakami basin. [Fig.1]

In the climate during the season (from April to October) when apple trees are in full activity, there is similarity between

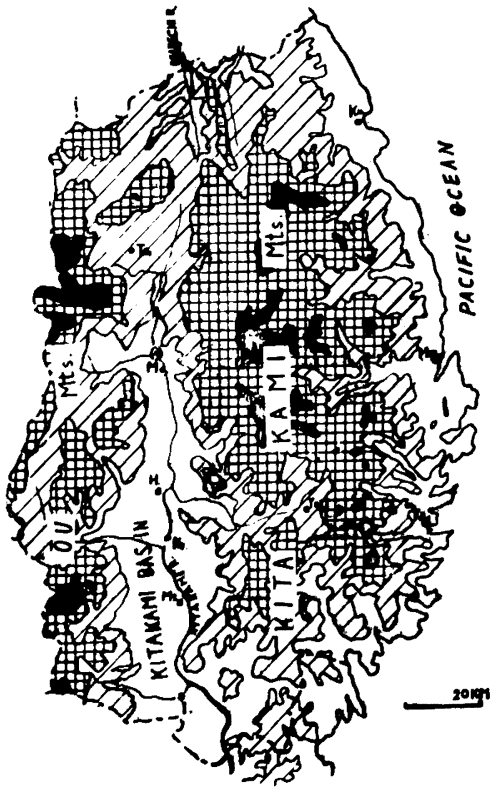

Fig. 1. Index map of Iwate Prefecture Ta: Tairadate, Mo: Morioka, $\mathbf{H}$ : Hanamaki Ki: Kitakami Mi:Mizusawa, I : Ichinoseki, Ku : Kuji, Miy : Miyako Ka: Kamaishi, To: Tôno

(1) Economic Division, Aomori Prefecture : Outline of the latest saling circumstance of fruits, 1956. 
Morioka and Aomori, but that of Morioka is more suitable for growing apple trees, because the mean temperature in the area goes up and down earlier in spring and autumn, and the precipitation is low in August and high in October. Especially, a smaller number of rainy days during the maturing season of late matured apples, helps to produce apples of better quality with nice colour. In the prefecture, each area shows a variety of climate. According to the comparison of the climates of typical representative 4 points, Tôno shows that of medium value between Morioka and Ichinoseki. The monthly mean temperature is $2^{\circ} \mathrm{C}$ higher but the monthly diurnal range is larger in Ichinoseki than in Morioka. Sakari belongs to the coastal area, where the diurnal range is small and early matured apples can be cultured fabourably, but the trees are apt to be damaged by agricultural chemicals on account of frequente foggy wheather. (Table 1)

Table 1. Climate of growing season of apple trees

\begin{tabular}{l|l|r|r|r|r|r|r|r}
\hline \hline & & April & May & June & July & August & Sept. & October \\
\hline & Aomori & 8.8 & 14.3 & 18.1 & 22.5 & 24.9 & 21.4 & 15.4 \\
Mean & Morioka & 9.2 & 15.0 & 19.2 & 23.1 & 24.9 & 20.2 & 13.6 \\
Temperature & TÓn & 9.4 & 15.4 & 19.3 & 23.2 & 24.7 & 20.0 & 13.2 \\
$\left({ }^{\circ} \mathrm{C}\right)$ & Ichinoseki & 12.0 & 17.3 & 21.0 & 24.8 & 26.6 & 22.0 & 15.9 \\
& Sakari & 11.8 & 16.4 & 20.2 & 23.7 & 25.8 & 22.1 & 16.6 \\
& Aomori & 9.9 & 10.1 & 8.1 & 7.3 & 8.2 & 9.3 & 10.3 \\
Diurnal & Morioka & 11.7 & 12.1 & 10.5 & $\mathbf{8 . 8}$ & 9.3 & 9.8 & 11.4 \\
Range & TOno & 12.1 & 13.3 & 11.4 & 9.4 & 9.4 & 10.0 & 11.3 \\
$\left({ }^{\circ} \mathrm{C}\right)$ & Ichinoseki & 13.4 & 13.7 & 11.6 & 9.7 & 9.9 & 10.2 & 11.8 \\
& Sakari & 12.3 & 12.0 & 10.8 & 9.5 & 9.4 & 9.6 & 10.9 \\
& Aomori & 81.1 & 71.5 & 81.5 & 128.7 & 128.4 & 143.3 & 114.3 \\
Precipitation & Morioka & 94.9 & 87.8 & 96.4 & 158.4 & 158.0 & 168.7 & 103.3 \\
(mm) & TOno & 90.2 & 91.4 & 95.2 & 155.8 & 142.3 & 157.4 & 110.4 \\
& Ichinoseki & 91.5 & 84.4 & 100.5 & 159.9 & 127.8 & 142.0 & 99.1 \\
& Sakari & 127.1 & 148.5 & 150.4 & 169.7 & 165.6 & 215.3 & 166.5 \\
& Aomori & 14.5 & 13.0 & 11.7 & 14.4 & 12.6 & 15.9 & 17.2 \\
Rainy Day & Morioka & 13.6 & 13.7 & 13.2 & 15.6 & 13.8 & 15.8 & 14.0 \\
(ฏ1.0mm) & TOno & 11.9 & 11.6 & 11.4 & 13.6 & 12.7 & 14.4 & 12.3 \\
& Ichinoseki & 10.0 & 10.8 & 11.1 & 13.4 & 13.8 & 13.5 & 11.2 \\
& Sakari & 10.5 & 11.3 & 11.8 & 13.6 & 13.5 & 14.5 & 11.7 \\
\hline
\end{tabular}

Source of data: (The Sendai Meteological Observatory : Climate of Tohoku Districts, 1951)

In Iwate Prefecture the degraded soils from granite, andesite and limestone and tuff are broadly distributed, and well drained. In the part whose soils are composed of heavy clay, deliberate tilling is necessary for apple growing, and in other parts sloping land is utilized for the purpose. Especially, most apple fields are distributed on the gentle slope of hilly land with the inclination under $14^{\circ}$ where terraces are not constructed. And apples are also raised on fans and natural levees. 


\section{History of Apple Gulture}

The origin of apple growing in this district is the same as that of Aomori Pref., and it began in 1875 when young plants of apple trees were delivered to the prefectural authorities by the Government. Since then, 1) the promotion of the culture by the pref., 2) the propulsion of the culture by the fruit cooperative association that was established in 1883 , and 3 ) the shipment of apples to Tokyo by railway which was opened to traffic in 1890-they popularized apple growing all over the prefecture.

But the level of cultural techniques was so low and the damages by noxious disease and insects were so severe that the number of apple trees fell down to 50,000 during 1920'25, from the peak of 1,150,000 in 1905. In Aomori Prefecture, however, in spite of the same circumstances with Iwate Prefectural authorities and apple raisers there, they found a way out of difficulties. On the contrary, in Iwate Prefecture, no effective measures against the damages had been taken, and this is the very reason why the apple culture fell into stagnation after the time. But after 1922, those interested in apple culture went every year to the apple growing areas in Aomori Prefecture to observe and learn the cultural techinques there, and endeavoured to spread the techniques over the prefecture. In this way, the apple culture was revived with fruitful results and experienced renaissance. Since then, each of them has contributed to the formation and development of apple growing areas, so that the apple fields are observed at present around the areas where they lives). The role the cultural technique played in forming the agricultural region and in its development process should not be underrated. Thus the apple growing areas have been firstly established in Morioka city and in its neighbourhood, though surpassed by Aomori Prefecture in development.

Only a small area of apple-fields was converted from dry-fields during the time of good business condition, 1918-19, because the culture has begun in earnest since 1922. During the period 1925-'35, however, when frequent panics and failures of rice-crop occured, farm economy was generally under strained circumstances, whereas the farm management including in it apple growing showed stability, so that many farmers introduced apple culture for the benefit of diversifying their management system and as the measures against the cool damage to paddy-rice, encouraged by the government. The apple growing areas expanded into the Tôno basin and the middle and southern parts of the Kitakami basin

2) These communities are Kawaguchi, Otobe, Iioka, Yanagawa, Mimae, Nagaoka, Kemuriyama, Furudate, Hizume, Maesawa, Tôno, Fukuoka, Kintaichi, Yonesaki, Mizusawa, Numakunai etc., and they cover the most of apple producing areas. 
during this period.

The apple fields occupied 5,600 acres in area in 1952, showing 8 times as large area as in 1925, though the production of apples decreased during the war time. And it seems that 1,000 acres of apple fields are newly increasing every year. The main varieties of apples are Jonathan and Ralls Janet. Especially, the culture of Jonathan is best suited to the natural characters of the prefecture, and the apples of that varieties are of excellent quality. 377,000 boxes of them were shipped by train and 134,000 boxes by truck from the prefecture in $1949^{\prime \prime}$.

\section{Areal Division of Apple Growing Areas.}

From the macro view-point the quantitative changes of apple growing are as follows: Up to about 1910 the number of the trees was the largest in the neighbouring area of Morioka city (Area A), and second to it in the area contacting with the eastern half of Aomori Pref. (Area B) and in the middle part of the Kitakami

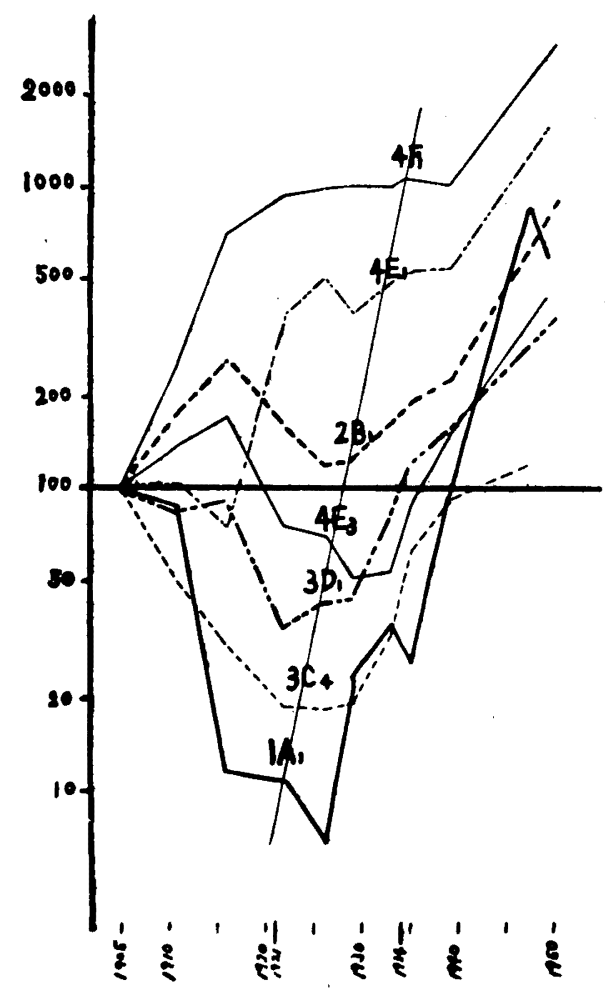

Fig. 2. Changing trends of apple fields in each area

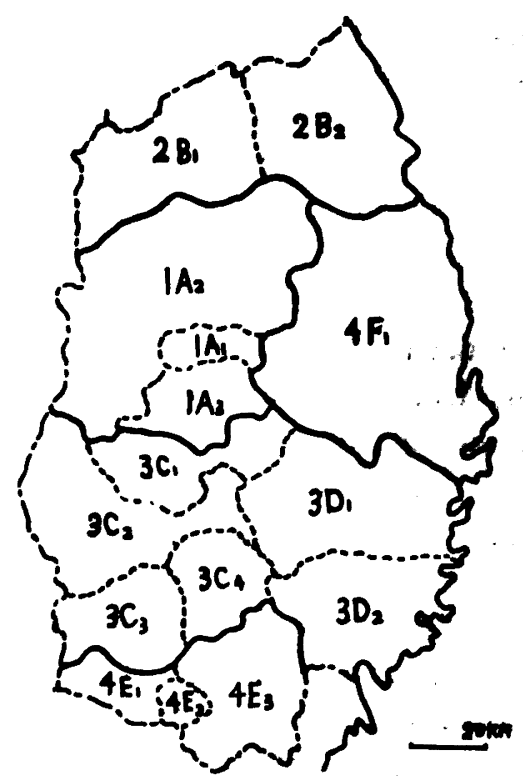

Fig. 3. Areal division |1]

3) cf. Kensuke Sadamori : Apple Growing in Iwate Prefecture, "Apple", 1952 pp. 187-194 
Mts. (Area D). During the period of decadance between 1910 and 1920, Area B maintained the status quo and the growing in Area A and D was enormously on the decline. Next, the growing experienced renaissance first in Area A, stabilized in Area B and prevailed in the middle (Area C) and southern (Area E) parts of the Kitakami basin. In other words, frequent and larger fluctuation took place in the developed areas, and the contacting area with Aomori Pref. had the same tendency to change in response to it, and the rest changed slowly. The present core areas of apple growing are Areas A, B, C and D. Based on the observation of this dynamic movement, 4 typical apple growing areas can be divided in the prefecture"). (Fig. 2, 3)

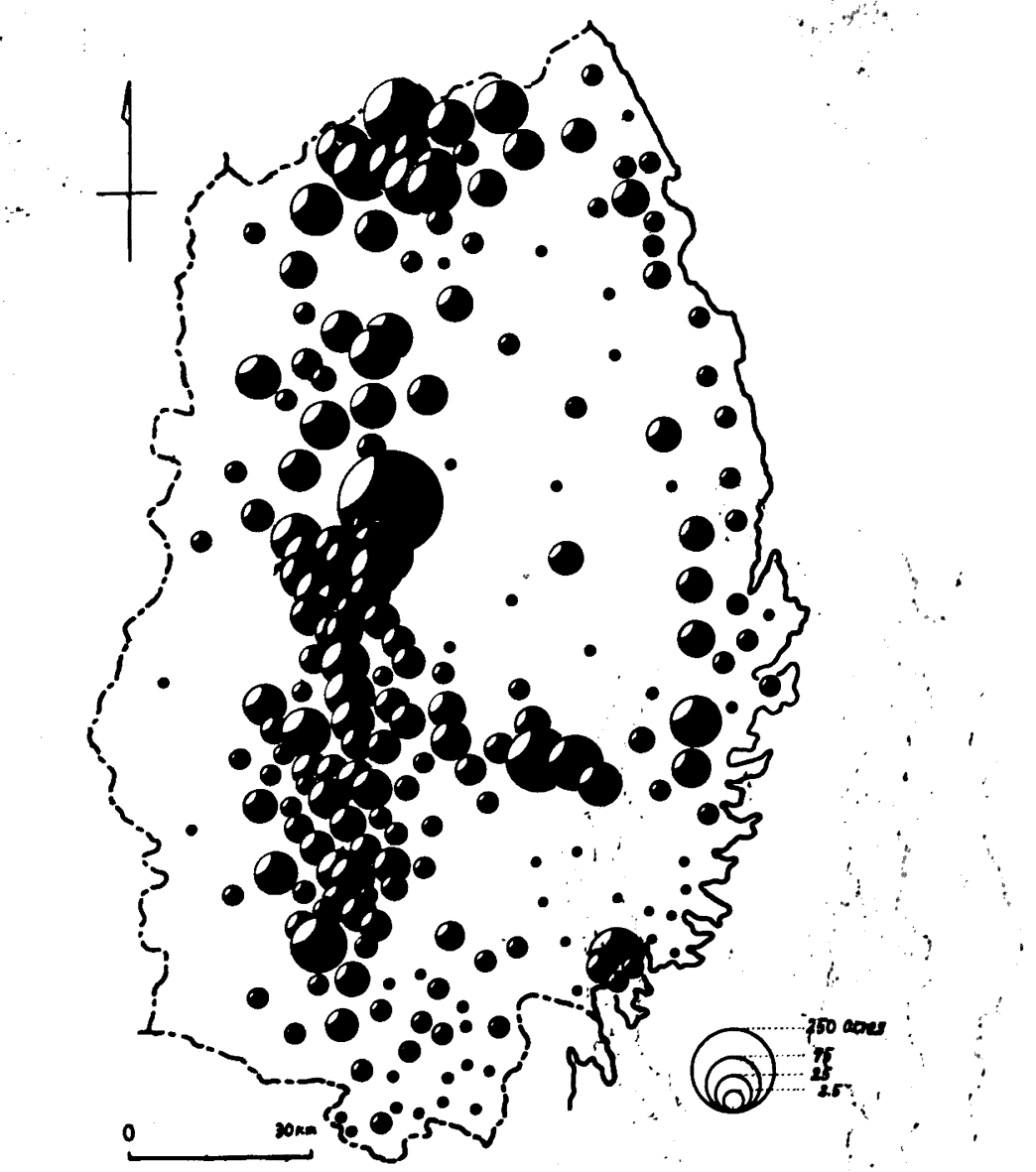

Fig. 4. Distribution of apple fields

(4) The data are obtainable from the "Statistical Year Book of Iwate Prefecture" in the period from 1905 to 1952 


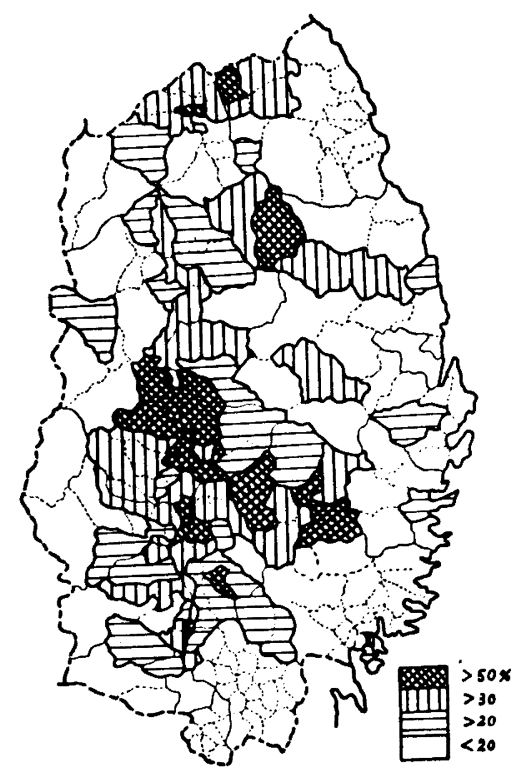

Fig. 5. Ratios of apple cultivators to tolal farmers

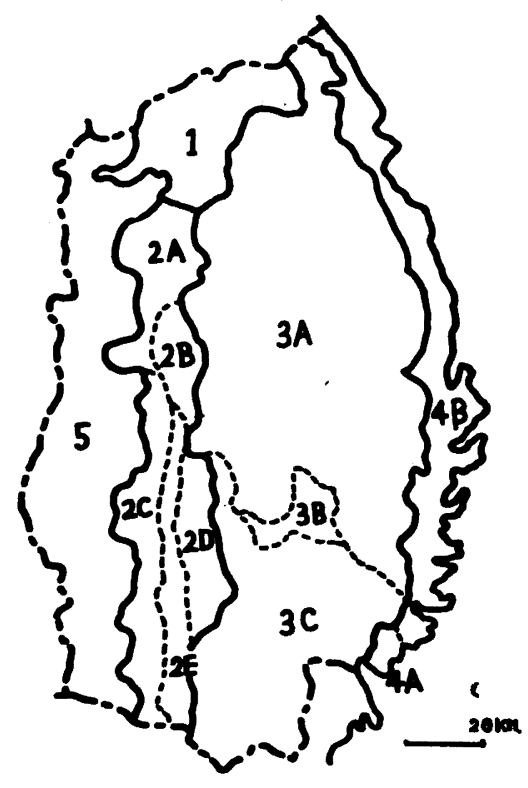

Fig. 7. Areal division $\mid 2$

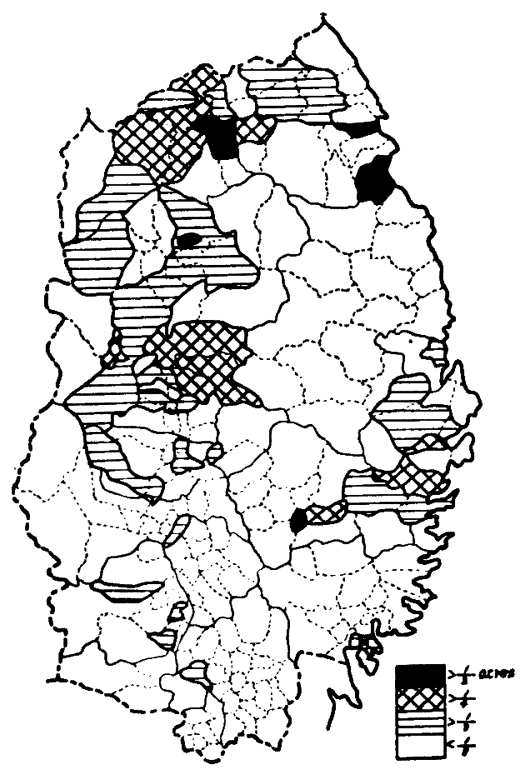

Fig. 6. Average area of apple field managed by apple cultivaters

1) The area where apple growing has been developed typically, but suffered from its larger fluctuation... the northern part of the Kitakami Basin ... Area A

2) The area which is contacted by Aomori Pref. and is strongly influenced by it ... upper part of the Mabechi Valley ... Area B

3) The areas where the growing has been rapidly increasing since the renaissance.. Areas $\mathrm{C}$ and $\mathrm{D}$

4) The areas in which apple culture has been spreading since the world war ... Area $\mathrm{E}$ and the northern part of the Kitakami Mts. (Area F)

Furthermore, to examine the characters of the areas in detail, 3 distribution 
maps were drawn up ${ }^{5}$ (Fig. 4,5,6). They were prepared for the explanation of the distribution of apple-fields, the ratio of the farmers adopting the culture to all the farmers in each area, and the importance degree of the culture adopted by the farmers. Then, Iwate Pref. can be divided into 5 major areas and 12 subareas viewed from apple growing, consulting effects by field work (Fig. 7). The characters of each area will be mentioned in next chapter.

\section{Characters of Apple Growing Areas}

1. Apple Growing Area Contacting with Aomori Prefecture.

This is the area belonging to the upper part of the Mabechi valley, where apple fields are distributed with an extent of 1,700 acres. Human activity in the area is functionally combined with Sannohe County," Aomori Pref. The origin of apple growing is the same with the neighbourhood of Morioka, but the culture has been more influenced by that of Aomori Pref. Namely, the apple raising there was annihilated in 1910, but it has been restored promptly by the learning of the cultural technique in Aomori Pref. Essentially the main income of farmers was gained from dry-field farming and forestry, not from paddy-field (under $1 / 4$ acres per farmer) farming, and they were very poor. Furthermore, the area is attacked by cool damages almost every year. For this reason the coefficient of variation of paddy rice per acre indicates $30-50 \%{ }^{\text {" }}$ Many farmers have actively introduced apple growing as a measure against these circumstances since 1920 . They manage 0.8 acres of apple fields on an average, but only 40 percent of them sell their products. Those who are engaged in both rice growing and apple growing have been more stabilized in management in this area like other areas. As the income from miscellaneous cereals is paid for the fertilizers to be used for paddy growing, apple culture is of profound significance for farmers. Generally, small apple fields are dispersed in sloping lands, so that cooperation and mechanization are difficult in operation.

Poor farmers manage apple fields on a small scale on small slope land with inconvenience to operation, and adjust themselves to commodity economy; this is the character of the area.

2. Apple Growing Area in Kitakami River Basin.

The core of apple production exists in this area. The basin forms a central

(5) The data are found in International Agricultural Census in 1950, The Table of Basic Survey, Iwate Prefecture.

(6) Takeo Ishikawa: The Study of Location of Fruits Production. pp. 218-220.

(7) Hatsuo Yasuta : Distribution of C. V. of Rice Yield per Tan in Japan, Annals of the Tohoku Geographical Association Vol. 8 No. 2 1955. pp. 37-41

Iwate Prefecture: Distribution maps of damages in Iwate Prefecture. 1950 
district of all the industry in the prefecture; it is dense in population and paddyfields are predominant.

A. The northern part from Takizawa Gorge.

It is a special feature in the area that apple fields and cabbage fields are managed by small-scale farmers together with paddy-fields and selfsufficient crop fields. Apple growing has been influenced by that of Aomori Pref., and it has been developed as commodity production since the latter half of 1920's. Barley, barnyard millets and soy beans are still main crops, and cabbage; apples and tobacco are also important. Most farmers grow cabbage on nearly 10 percent of their dry-fields. As the climatic condition of the area is suited to the growth of cabbage, it has become the main source of their farm income since 1873 when the severe cool damages attacked this area, reaching 1,700 acres in area in 1951. But lower class farmers must rely on the income from cabbage growing for purchasing fertilizers and to use for the fields of other crops. Only 10 percent of the total farmers in number in the area are engaged in paddy growing and the area of their dry-fields is as small as 1.2 acres on an average, consequently, besides self-sufficient crops, they are forced to raise cash crops with higher sale ratios to respond to commodity economy.

The Tairadate and Shizukuishi Basins have similar characters in agricultural system to this area. A large area of uncultivated waste-land is characteristically distributed there, and the area is known as a horse-producing one.

B. Agglomerated apple cultural area around Morioka city.

The development process of the apple production in Iwate Pref. is typically shown in the area. Apple raising began in 1870's and declined on account of various damages after 1910 , but since 1921 it has been adopted by many farmers as a kind of fabourable money crops owing to the introduction of the techniques in Aomori Pref. The cultural technique is most advanced at present in the prefecture as exemplified in the "noncover raising" of apples which the initiative has been taken in among other areas. The adoption of apple growing was firstly begun by landowners and rich farmers, and after the renaissance apple fields were increased in gentle slope land by other farmers, where national forests and the land owned in common were divided or disposed by the government and communities, and the land were used as dry-fields. Then german millet and barnyard millets disappeared and vegetable growing decreased in the area. The farmers in the western or northern parts of Morioka city are specialized in apple farming, and they seldom manage paddy-fields. In the sourthern sections of the area 90 percent of the farmers raise apples and paddy-rice for self-sufficiency. (Table 2. I, II)

C. Area of fans in the western part of the basin. 
Table 2. Character of individual farm in typical apple growing areas.

I. Mitsuwari Village in Morioka city (2B)

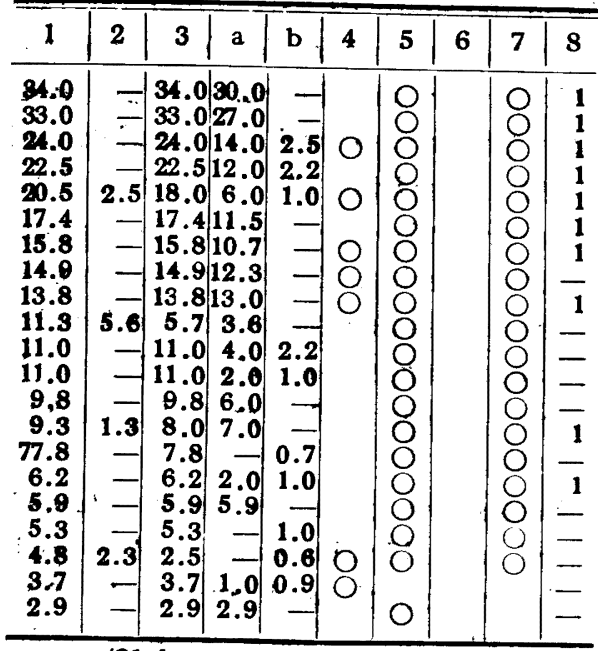

(21 famers sampling from 42)

II. Mon Village, southern vicinity of Morioka city.

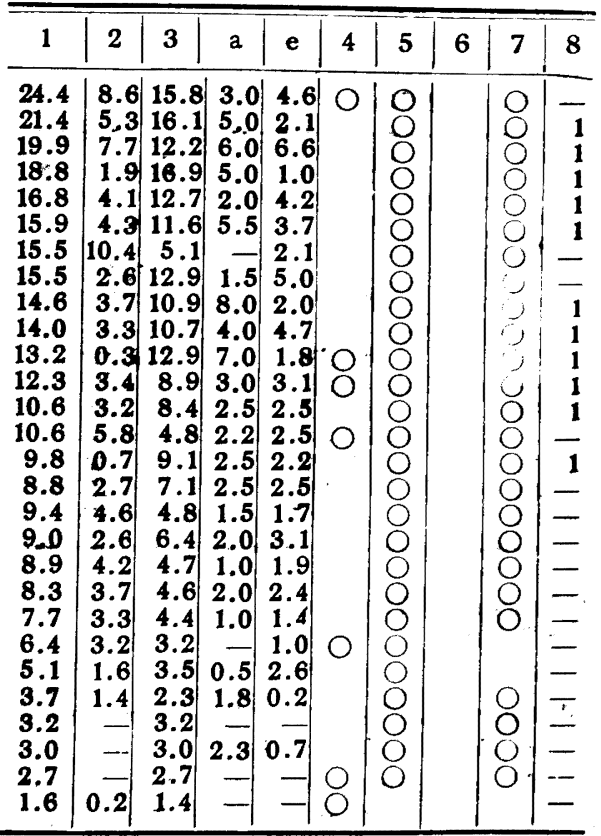

(23 farmers sampling from 55)
III. Mokurogi Village at Maesawa (2E)

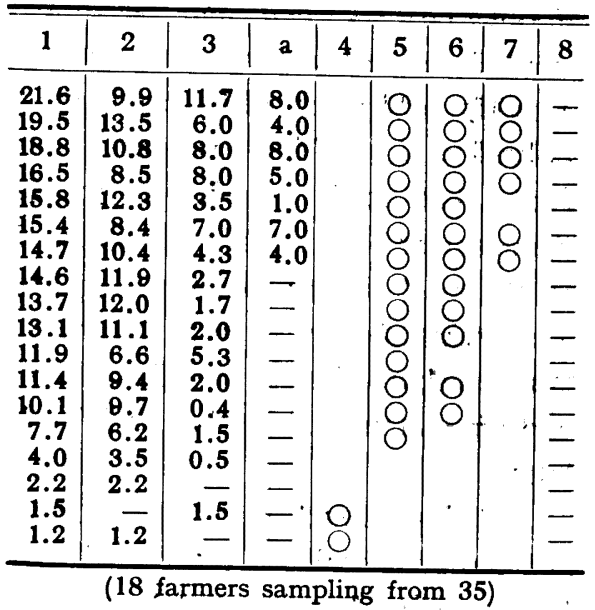

IV. Kanda Village at the Yonesaki area (4A)

\begin{tabular}{l|l|l|l|l|l|l|l|l|l|l}
\hline \hline 1 & 2 & 3 & $a$ & $b$ & $c$ & 4 & 5 & 6 & 7 & 8 \\
\hline
\end{tabular}

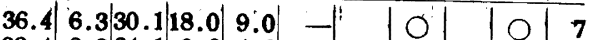

\begin{tabular}{l|l|l|l|l|l}
32.4 & 8.324 .1 & 0.6 & 4.6 & 17.1
\end{tabular}

\begin{tabular}{ll|l|l|l|l}
17.7 & 3.7 & 14.0 & 3.5 & 3.0 & -
\end{tabular}

\begin{tabular}{ll|l|l|l|l|}
16.5 & 3.5 & 12.0 & 5.5 & 3.5 & 2.0
\end{tabular}

16.1 1.914 .211 .0 1.0

$\begin{array}{llllll}14.9 & 3.2 & 11.7 & 4.0 & 2.3 & -\end{array}$

$\begin{array}{lllll}14.2 & 4.9 & 9.3 & 1.5 & -\end{array}$

\begin{tabular}{l|l|l|l|l|l}
10.6 & 2.3 & 8.3 & 2.0 & 2.3
\end{tabular}

\begin{tabular}{ll|l|l|l|l}
9.1 & 1.4 & 7.7 & 2.0
\end{tabular}

$\begin{array}{lllll}7.3 & 1.5 & 5.8 & 4.0\end{array}$

\begin{tabular}{lllll}
6.4 & 2.0 & 4.4 & 2.4 \\
\hline
\end{tabular}

$6.02 .53 .5-1.20 .3$

$\begin{array}{llllll}5.7 & 1.2 & 4.5 & 1.5\end{array}$

$4.8-4.82 .8$

$4.5-4.51 .03 .5$

$2.3-2.3$

$1.8-1.8$

1) Total of crop area $(\tan )$

2) Area of paddy-field ( $\tan )$

3) Area of dry-field (tan) a. Apples (tan) b. Sand pear (tan) c. Grapes " e. Vegetables "

4) Engaged in other occupations

5) Farmers earning the value of more than 50,000 yen of farm products sold

6) Farmers earning $>100,000$ yen by saling rice and barley

7) Farmers earning $>50,000$ yen by saling other farm products

8) Owner of agricultural machines (such as cultivator, hand tractor, powered sprayer, etc $)_{\text {) }}$

$$
\left(1 \tan \fallingdotseq \frac{1}{4} \text { acres }\right)
$$


Apple culture began earlier in the northern part of the area, influenced by Morioka city (B Area), and began after 1934 in the southern part. In these fans areas there are two kinds of sections; one is the sections where dominant land-use is paddy-field practised by conducting irrigation water, and the other is the areas utilized as dry-field or grass-land. It is in the former area such as Furudate and Fudô that apple growing is popularized. At Furudate, the weight of farm management is laid on rice-raising, and apples are grown by 70 percent of the farmers as the most important item of supplementary farming. For the purpose of overcoming the lack of farm income in the off-crop season caused by preponderation to rice culture, former miscellaneous crop fields are changed into the fields of early maturing variety of apples, and further changed to those of late maturing variety later.

At Toyosawa fan, ${ }^{8}$ ' wheat, barley and miscellaneous crops are mainly planted, and the area makes a remarkable contrast with a paddy-rice area. A few apple fields can be observed, but they are managed insufficiently and extensively (200300 boxes of apples are produced per acre). The management system which include apple culture together with other crop farming is the most stable (Tabel 3), accordingly apple raising is increasing more and more, though it is in the stage when some of upper class farmers adopt it at present.

D. Hilly land area near the southern part of the basin."

Table 3. Comparison of earnings and expenses between 3 farming types at Yuguchi-Mura ${ }^{(8)}$ (2C Area), 1953

\begin{tabular}{l|r|r|r}
\hline & Type A & Type B & Type C \\
\hline Area of paddy-field (tan)* & 15.7 & 10.3 & 14.6 \\
Area of dry-field & 1.7 & 6.0 & 4.1 \\
Area of apple field & -7 & 1.3 \\
Total crop area & 17.4 & 16.3 & 20.0 \\
\hline Whole income (yen) & 224,254 & 150,334 & 263,368 \\
farm expense & 40,934 & 26,468 & 52,714 \\
net income & 183,320 & 123,866 & 210,654 \\
\hline Whole income per tan & 12,466 & 9,131 & 13,133 \\
farm expense per tan & 2,353 & 1,624 & 2,256 \\
net income per tan & 10,113 & 7,505 & 10,877 \\
\hline
\end{tabular}

Type A : Farm specialized in rice culture.

Type B : Farm laid emphasis on both paddy-fields and dry-fields.

Type C : Farm managing apple fields on a small scale. - 1 acre $=4.03$ tan

(8) Norio Hasegawa: Investigation of Farm Management. Report of the Investigation on the Development Planning of Yuguchi Mura, 1954 pp. 1-28.

(9) cf. Norio Hasegawa : Farming System of a Hill-land Area in Kitakami Mts., Report of the Investigation for Multi-purpose Development Planning of Kitakami City, 1956, pp 10-30. 
In the western fringe of the sourthern part of the Kitakami Mts., small basins surrounded by dissected hills are dispersed. Rice culture is maintained by many small irrigation reservoirs. And cool damages and damages from a drought have seriously influenced the farmers, who have hoped to introduce any money crop. With the cool damage of rice in 1934, apple culture has been introduced with tobacco growing in earnest in the area. As tobacco culture needs to manage with highly intensive labour and can be begun without capital, lower class farmers have considerably introduced tobacco, and apples are cultured by upper class.

The slope land of hillside is covered by thick weathered soils from andesite which is suitable to growing apples, and Jonathan produced in the area is of the best quality in Japan. Diversified agricultural system is universal, but it aims at self-supply of foods for half of the farmers. They are many small scale farmers who are engaged in other occupations. These circumstances indicate the complicated characters of hilly rural districts, thus apple growing is becoming more and more important (table 4).

Table 4. Comparison of production cost between rice and apples. (per tan) At Kuchinai ( $(2)$ (2 D Area), 1955

\begin{tabular}{|c|c|c|c|c|c|}
\hline \multirow[b]{2}{*}{ Production cost } & \multirow[b]{2}{*}{$\begin{array}{l}\text { farm expense } \\
\text { self-sufficient } \\
\text { depreciation } \\
\text { total }\end{array}$} & \multicolumn{2}{|l|}{ rice } & \multicolumn{2}{|c|}{ apples } \\
\hline & & $\begin{array}{c}\mathbf{3}, 967 \text { yen } \\
8,216 \\
858 \\
13,041 \\
18,226 \\
5,962\end{array}$ & $\begin{array}{c}30.4 \% \\
63.0 \\
6.6 \\
100.0\end{array}$ & $\begin{array}{c}20,576 \text { yen } \\
14,324 \\
6,440 \\
41,340 \\
57,596 \\
12,904\end{array}$ & $\begin{array}{l}49.8 \% \\
34.6 \\
15.6 \\
100.0\end{array}$ \\
\hline
\end{tabular}

E. Alluvial plain area in the sourthern part of the basin.

This is a frequently flooded alluvial area which is studded with apple fields along the Kitakami River in the sourthern part of the basin. And over 70 percent of arable land is paddy-fields of single crop a year. Natural levee and the part suffering hard from flood are used for dry-fields. Apple culture has developed since 1934. On the depression of sericulture and lucrativeness of apple raising, apple growing has been introduced into the vicinity of Mizusawa city. At Maesawa, as the land is habitually damaged from flood, land utilization is so unstable, and planted crops are completely destroyed at the time. Consequently, the farmers have racked their brains to gain farm income from the field securely, and have planted various crops in the last 50 years, such as wheat, barley, soy beans, cabbage, mulberry, rape grains, tobacco and indigo-plants. But once the fields sustain a loss from flood, they have bad harvest. Whereas a half of the normal yield of apples can be harvested at least even in a damaged year, and apple culture has been adopted there. 
The farmers adopting apple raising manage 1.7-2.0 acres of paddy-fields and 0.7-1.0 acres of apple fields. Suffering from the damage of flood, the lower class farmers cannot introduce apple growing owing to lack of money (Table 2, III). The neighbouring area of Ichinoseki is damaged more severely from flood, and apple culture has not appeared yet.

3. Apple Growing Area in the Kitakami Mts.

A. The middle and northern part of the Mts.

This is a mountainous, sparsely populated and underdeveloped ${ }^{10)}$ area (paddyfield : $1.0 \%$; dry-field : $6.0 \%$; forest and waste land : $93.0 \%$ ), where backward agriculture is dominant and combines a little apple raising with it. From the selfsufficient production type, by which the production of wood and charcoal and barnyard millets raising are the prop and stay, agricultural system is changing by degrees to dairy-farming. ${ }^{11}$ As the area corresponds to the most exterior of Thünen's isolated nation, facilities of communication are not available to access and transport cost is higher, so that the development of apple growing necessitating intensive labour is difficult (Fig. 8). Furthermore, the land is unfit for apple

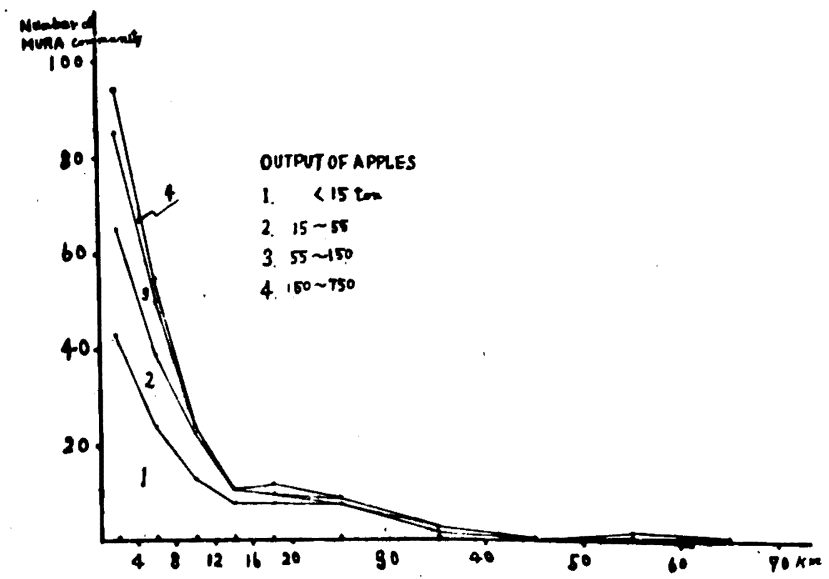

Fig. 8. Relation of output of apples to distance to railroad depot from producing area.

culture; the damages from cool and frost frequently attack it; and pre-modern social relationship still exists tenaciously between big forest land-owners and poor

(10) Ryujiro Ishida : A Note on Barnyard Millets in Kitakami Mts. Ichikyo Ronso Vol. 35 No. 3 pp. 206-222.

(11) Ken-ichi Tanabe: Formation Process of $\mathbf{M}_{3}$ Milch-Cow-Keeping Region in North' eastern Part of Kitakami Mountainland. Science Report of Tohoku Univ. 7th Ser., No, 5, 1956. pp. 110-128. 
farmers. Under these circumstances, many farmers have not enough capital for introducing apple raising, though a few farmers plant apple trees, and only 10 percent of them grow apples for sale. The significance of apple growing is too small in the area.

B. Tono Basin

The Tono Basin is an erosion basin (Ausräumungsbecken) in the upper valley of the Saruga-ishi, where $\mathbf{5 0 0}$ acres of apple fields are distributed in extent. Apple growing has revived since 1920, and has acquired importance as a cash crop since 1934 when the harvest of rice was bad. Each farmer introducing apple culture manages 0.7-1.0 acres of apple fields on the slope land. For the sake of spraying agricultural chemicals for prevention and extermination of the damages from diseases and insects, knapsack sprayers are still used, and the area also falls behind other areas in other techniques. $70 \%$ of the farmers producing apples sell their products, but there is no near-by market, so that their family must peddle to Kamaishi city and others.

C. Southern part of the Kitakami Mts.

The land-use is fairly advanced on the hilly land (paddy-field : $24 \%$; dryfield : 24\%; forest and waste land : $52 \%$ ). Except small paddy-fields, wheat, barley and other cash crops such as tobacco and mulberry are raised in the slope land. Most farmers adopt sericulture and tobacco growing, and apple production is not prevailing.

4. Apple Growing Area along the Coast.

According to lack in hinterland and inconvenient transport condition, fishery is not prosperous, though marine products are rich near the coast. The small plains along the streams are used for agriculture. And many farmers are engaged in fishing. Apple growing is not flourishing except the Yonesaki area, southern part of the coastal area. Owing to the influence of the fog in spring and the sea breeze, the apple trees have frequently been damaged from agricultural chemicals and the fall of leaves. A market is found at the local cities along the coast.

A. Yonesaki area.

It is a small area in the southern part of the coast, and it is characteristic of this area that the culture of sand pear was in a prosperous condition in former days and apple growing is predominant at present. In spite of facing the sea, fishing has a poor catch, and unavoidably the residents must be engaged in sericulture and emigrating carpentry. Sand pear culture was introduced in 1880's by a carpenter, and then $2 / 3$ of the dry-fields were once occupied in area by sand-pear raising; converted from barnyard millets- and barley-fields. The failure of sand pear growing and fishing gives impetus to the introduction of apple 
culture, and apple fields have been increased. As things are, 70 percent of the fruit trees are apples and the rest are sand pear, grapes and peach trees. In this area the food stuff of the farmers can be produced and secured within only 3 months, consequently market agriculture such as apple growing is extremely important. Many farmers manage 1.0-1.2 acres of apple fields on an average, and large scale farmers plant diversely some kinds of fruits. The equipment for spraying of agricultural chemicals is modernized, and the study of cultural technique is fairly progressed (Table 2, IV).

B. Other part along the coast.

10-20 percent of the farmers adopt apple growing in a small area, and at several sections a few cultivators manage 0.5 acres of apple fields. Owing to frequent cool damages, the restraints of land owners and smallness of arable land, the farmers managing on a small scale must be engaged in wage-labour, and agricultural operation is apt to be left to women. Only farmers of upper class have introduced apple growing since 1934, and completed their living expenses by it.

5. The Ou Mts. Area.

Industry is specialized in forestry. Allotments of paddy-fields are distributed at the small plains of streamside, and miscellaneous crops are cultured in dry-fields, but apple culture has not yet been introduced.

\section{v. Summary and Conclusion}

As a whole, the apple growing areas in Iwate Pref. show diversity in nature. There are various areas; in some self-sufficiency farming is dominant and in others marketing crop farming is popularized under the bad conditions such as cool damages and flood damages to rice crop, in addition to intricate geomorphology and climate. And, apple culture is newly associated with crop farming, and complicated apple growing areas are formed.

The apple growing areas are firstly divided on the criterion of the quantitative change of apple trees, and nextly divided on the basis of the characters that the apple culture bears in the system of general industry, especially the agricultural structure of the areas. It is not the division method by using an indiscriminate or synthetic index, but an areal division by taking into due consideration the actual circumstances of apple culture in Iwate Pref., so the detailed description of the actual conditions of each area should be made for the sake of the better areal division.

From the present study, however, it is possible to draw some problems with regard to the formation of an agricultural region. One is concerned in the 
development stage of a new agricultural region. By investigating into the characters of the farmers who played and are playing the important role in such an areal formation, the present development stage of the area and its nature may be revealed, and the economic sidelight of the formation of an agricultural region in its higher and next stage may be guessed. The areal difference of the way of the introduction of apple growing into the management system of farmers, and the association of apple raising with other ways of farming in a dominating paddy rice area or selfsufficient dry-field area and others : they have been compared with to make them serve the very purpose to investigate into the problem. And these informations will be provided for the next report which will treat with the vital elements contributing to the formation and development of a new agricultural region.

From another view-point, there is a problem referred to the significance of cultural technique in the development process of a more advanced agricultural region which is formed on the foundation of the former agricultural system of the region. In the stage in need of the intensive manual labour as generally seen in Japanese agriculture, the acquisition of a new cultural technique and its propagation is necessary of popularizing a new farming and expanding a new agricultural region. And this is applicable to the case of apple growing in Iwate Pref. To examine the problem more closely, the author is planning to show the case in Akita Pref. 


\section{岩手県におけるりんご栽培諸地域}

長谷川典夫

此の般告は岩手果のりんこ生産諸地域の性格を概述した ものてある。生産量は日本の 5.0\%を占めるに遇きないか 1949 年の 1818 町から 1955 年には 3590 町と 2 倍の面 稳增加を示す程岩手紫における戦後のりんこ生産の発展は

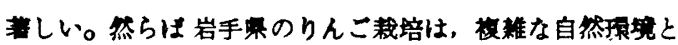

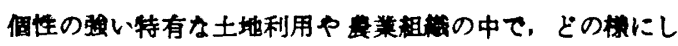
て導入され発展して来たか？そしてどの棣な多粎なりん

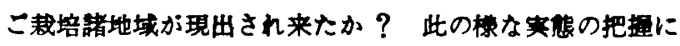

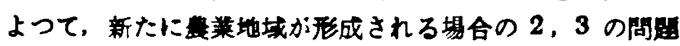
点考宗の料を满し，足かかりを見出すことが出来よう。

I. 岩手累は東西を夫れ北上山地及び奥羽山脈によつて 占的れ，中央部て壮北部は馬涇川流域，中南部は北上川 の其流する北上河谷盆地となつている。盆地西側には屌状 地群が発连し，北上山地の中南部ては侵螌小盆地や丘陵性 地形が展開する。太平洋岸は被鹤な所謂リアス式海岸で 万。

りんこ懝の生奇期間の気候は青森地方と類似するが，内 陸部は気温敖差が大きく、果実の着色を容易ならしめ，海 岸部ではガスや湖風の為莱客を起す事もある。

花崗岩安山岩石兏岩の崩解土が多く，排水良くりんこ栽 培に道する。

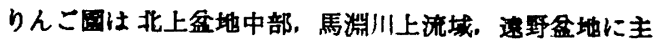

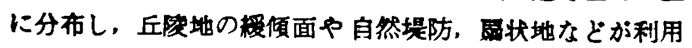
される。

II. 岩手果のりんこ载培の㞎源は青森累と同しくく 1875 年に政府より苗木配布を受けた事に始まる。その後諸条件 の整销によつて発展を見たか，病虫宫発生の為 1905 年以 阵变䃍し 1920 年代には 50,000 本にまで楜数の娍少を見

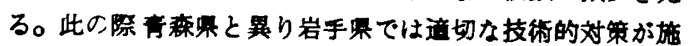
されなかつた為，得興汢おくれた。1922年以降溨培者有志

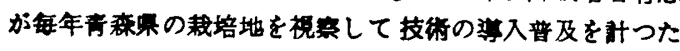
のて再ひ郢盛に向つた。彼等のりんこ栽培に果した役割が 非常に大きかつたので，現在でもりんこ栽培地域は彼等の 住む地域を中心に展開されている。農業地域の確立過程に 於ける栽培技術の果す役割は大きい。1925年以降恃不況や 凶作を契機にりんこ導入は更に促進され，栽培地域も北上 盘地の中南部や速野盆地に桩大されて行つた。

III. 郡別の量的消长とりんこ園分布，りんこ栽培浝家 数の割合， 1 戸当りの栽培面摔を参考にし，具体的調查に よつて性格を别けて，次の如くりんこ载培地域を設定する。 IV. 1. 青森紫に隣接し，その影を強く受けた馬淵

\section{川上流地域}

2. 北上河谷盘地内の栽培地域
A. 滰沢陕谷以北のりんこ栽培地域
B. 盈岡周辺の集中的りんこ栽培地域
C. 盆地西側展状地群の栽培地域
D. 南東部丘陵村の裁培地城
E. 盆地中南部冲稜地の栽培地域

3. 北上山地内のクんこ武培地域
A. 北上山地中部北部の刬培地域
B. 途野盆地のりんこ生産地域
C. 北上山地南部の地域

4. 海岸地茾のりんこ武培地域
A. 米崎のりんこ裁培地域
B. 大部分の沿岸栽培地域

5. 奥羽山脈の地域

V. 之等の区分は，特定な或は一律な指根を用いてなさ れたものではな。地域の産莱特に農莱の組機の中にりん こ载培が如何に粗合わされているか，如何なる段階で如何 なる实体を示しているかの考虔に基いた区分てある。

かくして岩手累のりんこ栽培地域恃多漛な性格を示す。

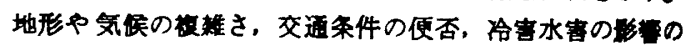
程度の相異と共に，徒来おかれて来た地域の羞菜の性格や 费業の発展の過型にも夫々特色がある。徒つてりんご栽培

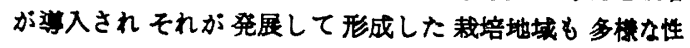
格，多棵な発展段陼を示す。

此の研究から演紧され得万問題が 2 つある。1 つは新し い最業地城が形成された㙋合のその発展段階についててむ る。夫々の性格を持つた地域て，新しい费業を过入する仕

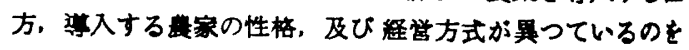
見る事によつて，時間的流れの中でのその発展段䏂を知り，

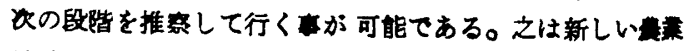
地域の形成及びその発展を考客する堨合の不可欠な側面て ある。

他の1つは,より有利且先進的なかつる農業地域か形成 され発展するに際しての, 栽培技術の重要性についててあ る。日本素で一般的に胃られる学做集約的な手学做を必 要とする段階では，新しい栽培技術の収得及びその伝楿恃 新しい農業地域形成に於ける必須の要件である棣に思われ る。此の事は岩手累のりんこ栽培の発展及び現在の分布地 域を調へる事によつて知り得だ一つの事实である。之に関 しては他の实例と并せて理論的吟味を别途に意図している 